\title{
The Philosophical Foundations of Corporate Social Responsibility in the Water Sector in Benin
}

\author{
Akowanou Clément Ahouandjinou, Cheikh Ibrahima Niang \\ Social Aspects of HIV/AIDS and Health Reseach in Africa Laboratory, The Institute of Environmental Sciences (ISE), \\ The University Ckeikh Anta Diop (UCAD), Dakar, Senegal \\ Email: akowcle@yahoo.fr
}

How to cite this paper: Ahouandjinou, A. C., \& Niang, C. I. (2021). The Philosophical Foundations of Corporate Social Responsibility in the Water Sector in Benin. Open Journal of Philosophy, 11, 516-527. https://doi.org/10.4236/ojpp.2021.114035

Received: October 13, 2021

Accepted: November 21, 2021

Published: November 24, 2021

Copyright () 2021 by author(s) and Scientific Research Publishing Inc. This work is licensed under the Creative Commons Attribution International License (CC BY 4.0).

http://creativecommons.org/licenses/by/4.0/ (c) (i) Open Access

\begin{abstract}
The presence of private operators in the water sector may seem paradoxical. On the one hand, they have their profit margin to preserve, and on the other, the social aspect to keep in mind. This is a real challenge. The private operator in the water sector must be able to embrace the culture and ethics of water in the environment. This study is conducted in Benin in the Ayizo cultural era in the rural commune of Zè in the arrondissement of Hèkanmè. In summoning up the culture, one realizes that water is the fruit of another person's sacrifice, and this implies doing everything possible to ensure that no one lacks it. The rationale for business in the water sector is that private companies in the global context of their emergence can play a constructive role in providing resources or expertise in situations where governments and states are increasingly weak and unable to adequately fulfil their role in the water supply. Corporate social responsibility in the water sector is reflected in the social dimension of pricing. The vast majority of people interviewed in the study area believe that users pay for water. In general, the price of water paid by the population is often lower than the real cost of the service. In addition, there is solidarity between large and small consumers. The vital nature of water requires integrated and sustainable water governance systems. Local citizens, communities and companies must be actively involved in its management.
\end{abstract}

\section{Keywords}

Social Responsibility, Water, Business, Life, Sacrifice, Ayizo

\section{Introduction}

Corporate social responsibility is a relatively new dynamic. It is, as Diop and Bah 
explain, "an integrative model to establish business ethics; combine economic, social and environmental development objectives and install a permanent relationship between stakeholders (Diop \& Bah, 2018)." Water is life and access to drinking water is essentially a vital and therefore social issue. So a company that is involved in supplying drinking water to the population must necessarily be social. And it would be like kicking down an open door to talk about the social responsibility of companies in the water sector. But it is known that the purpose of a company is to increase its profit. The question is, what is the raison d'être of companies in the water sector? Since the dawn of time, mythologies even before modern science have highlighted the link between water and life (Maneglier \& Schleiss, 2000). For this reason, corporate social responsibility in the water sector should be of particular importance. In this sense, the contribution of local culture, especially the cultural values related to water in the environment where these companies are located, should be decisive in the conception and formulation of their social responsibility. This study aims to formulate a critique of the exercise of corporate social responsibility in the water sector in Benin in the commune of Zè based on the cultural values related to water in the Ayizo cultural era.

\section{Material and Method (Sites, Populations and Methods)}

In Benin, the commune of Zè, one of the seventy-seven in the country, is located in the northeast of the Atlantic department of which is an administrative subdivision. With an area of $653 \mathrm{~km}^{2}$, it is the largest commune in the department, occupying $19.88 \%$ of its territory (Fahala, 2006). The commune of Zè is subdivided into eleven arrondissements (INSAE, 2016). Since the last census, according to Dangbénon, Mayor of the commune of Zè in 2016, the commune now has one hundred and one village (Dangbénon, 2016). The commune of Zè, with a total population of 106,913 according to the general census RGPH4 in 2013, is composed of 19,224 households with a household size of 5.6 (INSAE, 2016). This population is dominated by the "Ayizo" ethnic group which added to the "Ouèmènou" make $97.4 \%$ of the population. Next come the Yoruba (1\%), the Adja (0.8\%) and other ethnic groups (0.8\%). The district of Hêkanmè has 11,248 inhabitants. It has ten villages: Hêkanmè centre, Amangassa, Houéhounta, Agbata Djigbé, Agbata Wédji, Gbozounmè, Houédota, Djoko (Salanontomè), Awokpa and Togoudo.

The data used in this article were extracted from the work of the PhD student in environmental ethics. Data collection carried out from August 2016 to September 2017 was based on simple random sampling after allocating quotas by village. Of the 1796 households in the Hêkanmè district, ten households were surveyed in each of the ten villages of the district, including the households interviewed during the exploratory survey. This gives a threshold of $5.56 \%$. The methodology developed in this study is oriented around three axes: first, the literature review, then the collection of data in the field and finally the processing 
and analysis of the data. As regards the collection of data in the field, the focus was on qualitative data and was carried out through observations and interviews in the commune of Zè and also with other resource persons and institutions. It consisted in collecting elements of oral literature about water, myths, proverbs, riddles, songs and adages that convey cultural values around water in order to build on the water ethic present in the area. It then consisted of collecting from the population their evaluation, their criticism of the management of water works and their perceptions of the social responsibility of companies in the water sector in their area. The methodological approach adopted consisted of comparing the data in the literature with those collected from the populations of the study area.

\section{Results}

\subsection{Metaphysical Foundations of Responsibility}

In environmental ethics, one of the key concepts is the principle of responsibility. Hans Jonas devoted a reference work to this principle, The Responsibility Principle, an Ethics for Technological Civilisation. As Jean Greisch writes in the preface to this book, "for Hans Jonas, being responsible means accepting to be 'taken hostage' by what is most fragile and most threatened (Jonas, 1995)." In the search for a solid foundation for the ethics of responsibility, it is important to recall the centrality of metaphysics and to assume the fundamental concepts of purpose and vulnerability. Metaphysics must be used to understand the foundations of the ethics of corporate social responsibility in the water sector. Metaphysics alone clarifies man's responsibility. Man must not by his carelessness cause the disappearance of the world. Jonas (1998) also specifies how man should be and exercise his responsibility in the world. Man must be able to use his reason and find the necessary means to ensure a dignified and permanent life on this earth. In this perspective of recognizing in nature the sources of man's responsibility towards it, Hans Jonas is joined and supported by several authors, including Larrère \& Larrère (2009) and Rameix (1996). Hans Jonas started from the idea that the ethics of responsibility needs a new metaphysical discourse on being.

Commenting on Jonas (1995), Semde (2015) finds that "The theory of the end served as a propaedeutic for the theory of value insofar as the latter is to serve as the foundation of the new thought responsibility (Semde, 2015)." In the Ayizo cosmogony, the fact that water is derived from voluntary human sacrifice manifests that the purpose of water is to sustain life. Once the finality of all beings is established and their value recognised, it is the responsibility of man that is engaged precisely because of his higher level of consciousness.

In addition to finality, vulnerability also highlights the value of being, and thus engages man's responsibility towards nature. Finality and vulnerability are two characteristics that underpin the ontological value of being. Jonas (1995) has used these two characteristics to reformulate the principle of man's responsibility towards nature. The concept of vulnerability has a prominent place in Hans 
Jonas's elaboration of his new ethics of responsibility. For Semde (2015), "basing ethics on vulnerability is not properly a Jonasian invention (Semde, 2015)."

The question arises as to what Hans Jonas brings to the table when he uses the concept of vulnerability as a basis for the ethics of responsibility. The answer to this question seems straightforward for Semde (2015) and is stated as follows: "in line with the principle of all environmental ethics, Hans Jonas does not reduce vulnerability to humans, but extends it to the whole of nature (Semde, 2015)." Hans Jonas's thesis here is that the representation of a being as vulnerable must be accompanied from the outset by a sense of responsibility towards it. Thus for Hans Jonas (1998), "the demand for a Being of value becomes concrete by addressing me as a practical subject, if this Being is a vulnerable Being, as the living is always in essence in its fragility (Jonas, 1998)." For Semde (2015), "vulnerability must assume here the same role as that of the end: to bridge the gap between being and duty, so that responsibility as an ethical principle can receive an ontological foundation (Semde, 2015)." For Jonas (1998), "the choice of being against Nothingness stands as a categorical, unconditional imperative, from which all other principles of the ethics of responsibility can be deduced (Jonas, 1998)."

For Jonas (1998), “Humanity must be' is the imperative, the foundation of the whole edifice of the ethics of responsibility (Jonas, 1998)." We are facing new approaches to responsibility. As Côté (2006) explains, "continuing a movement that began in the era of solidarity, the object of responsibility is shifting from the damage to be repaired to the 'fragile' (Côté, 2006)." For Paul Ricoeur, "we are no longer responsible for what but for whom". Before, we were responsible for the causal chain of action-damage-repair; now, "moral responsibility encompasses the relationship "between the author of the action and the person who suffers it, the condition being that the latter is in a condition of vulnerability (Côté, 2006)." And man alone must answer for the fate of vulnerable beings. As Rameix (1996) shows, "man is that being which the preservation of the most fragile and the most threatened calls for responsibility (Rameix, 1996)." Beings are calling out to me. The cry of vulnerable beings calls for my responsibility. Thus the being of people who lack drinking water and the being of the water resource as an element of nature call for responsibility. And for Maillard (2011), "the moral subject is no longer 'the capable man', but the subject whose powers are affected, who is touched by the suffering of the other, who is destabilised" (Maillard, 2011).

\subsection{Values Linked to Water in Ayizo Culture, Cultural Foundations of Responsibility}

Water as an object of symbolic, mythical and mysterious representations is present in all cultures and in all cosmogonies of the world. It is part of the foundation of beliefs, mores and religions (Mêliho, 2014).

According to the data from the pre-investigation in the district of Hêkanmè, a myth was told to us to explain the origin of water. The second fragment told by 
Noutaï (2017) reads as follows. "A lady named Anansi with her child was on a journey. At one point, they were hungry and thirsty. They were at least looking for water. When they reached the house of an old woman, she gave them the little water she had. The Anansi woman, relieved to have some water, rushed to drink without thinking about her child. The child started to cry out of thirst. Not knowing what to do, the lady fell to the ground and asked God to do with her what she wanted. She sacrificed herself and turned into water so that the child could drink (Noutaï, 2017)." From this myth it is clear that water is the fruit of voluntary human sacrifice. Water is the fruit of a woman's self-sacrifice to save lives.

There are adages and proverbs related to water in Ayizo culture.

- "You don't refuse someone water."

- "It is not good to refuse water to a person." Respondent Noutaï (2017) reports that "a father used to say to his wife, grandpa who has already passed away, will come and eat at night, you should always keep food and water in the room (Noutaï, 2017)." Respondent Noutaï (2017) explains "[that] it must be understood that during the night a child can have problems, health problems, you always need water to prepare a tea (Noutaï, 2017)."

- "It is by uniting that ants manage to cross the tide." Thus the use of water as a source of life requires solidarity.

According to the data from the pre-survey carried out in the district of Hêkanmè, several prohibitions concerning water organise the life of the population.

- "In this environment, it is possible to poison with food and other drinks, except with water. This is forbidden. Whoever does so will suffer the consequences for life."

- "Water intended for the population, for passers-by, in a jar, do not throw things in there at the risk of being struck by lightning."

- "Those who stop the rain from falling can be struck by lightning."

\subsection{Perceptions of Corporate Social Responsibility in the Water Sector in the Ayizo Area}

The commune of Zè, which has benefited from numerous water projects, was one of the first to experiment with management by leasing in the year two thousand and ten (2010). It is a typical example of the first steps in the management mode by leasing. These leases were concluded with five companies for a period of three years, who were responsible for the works on the lots they were awarded; for the account, the municipality was divided into nine lots.

Criticism of the management of the farmers.

The dysfunctions of management by leasing in the commune of Zè are summarised in the document Professionnaliser les acteurs pour une gestion durable du service public de Peau des communes de Kpomassè, Toffo et Zè, in these points.

- The non-regular payment of fees by the farmers; 
- The high cost of the cubic metre of water in the areas where the $\mathrm{AEVs}^{1}$ are installed on the electricity network;

- The failure of generators;

- The lack of coverage of all the AEVs by the electricity network ( $\left.\mathrm{SBEE}^{2}\right)$;

- The calamitous management of the current operators after the suspension of the contracts of the previous farmers whose term has expired;

- The failure to set up a stock of spare parts to centralise the expenses incurred by the occurrence of breakdowns;

- The failure of the project owner to recruit an electromechanic (Moreau, 2013).

The opinion of the population:

In the general opinion of the stakeholders, the responsibility of the managers can be situated at three levels. A distinction is made between the responsibility of the farmer, that of the manager and that of the fountain manager.

Responsibility of the operator (the farmer):

A respondent from the village of Houéhounta noted that "breakdowns are taken care of by the operator". According to this respondent, "it is necessary to be diligent in managing breakdowns". For another respondent in the same village, "for better management, breakdowns must be avoided, and repairs and checks must be carried out within a reasonable time". For a respondent in the village of Awokpa, it is necessary to "have a technician to monitor the work, maintenance and repair of the work in all its components on time".

Responsibility of the manager:

According to a woman from the village of Houédota, "for a better management of the works, it is necessary to have regular maintenance of the machine, and to have a periodical control of the installations". And for a respondent from the village of Hêkanmè, "those who manage the castle must be of good character and credible". According to a respondent from the village of Amangassa, it is important to "repair breakdowns on time and ensure maintenance". As a respondent from the village of Togoudo advises, it is important to "put a person in charge of the works who will report the slightest malfunction", and as for a respondent from the village of Awokpa, it is important to "Maintain, protect and secure the installations well. Wash the tank, check the pipes and clean the installations. Routine checks by competent people in the field are needed to verify the installations."

Responsibility of the fountain operator:

For a respondent from the village of Gbozounmè, "the water sellers at the station must ensure that the water points are clean". In the opinion of a respondent from the village of Houéhounta, it is important to "prevent water sellers at the standpipes from being absent or going off to other activities". For a respondent from the village of Amangassa, "the managers of the standpipes must be on time at the water point for the sale and receive the users as brothers". As a respondent ${ }^{1}$ Village Water Supply.

${ }^{2}$ Beninese Electricity Company. 
from the village of Togoudo said, "For the sale, there must be a rotating management and a quota (amount) to be handed over periodically. If the quota is not reached, the person in charge of the sale fills the gap. The selling price must be average."

Accountability to the population:

The population has a right to control the management of waterworks. A respondent from the village of Togoudo believes that "if management is entrusted to a single person, everyone should have a say in its upkeep and maintenance". As a respondent in the village of Djoko put it, "if we see things that are not going well, we will say so". For another respondent in Djoko village, "after the sale, there must be regular collection of income and clear accounting". In the same vein, a respondent from the village of Hêkanmè maintains that it is necessary to: "recruit a person who will ensure the sale of water and the income from the sale must be publicly reported, and the population must be given an account." For a respondent from the village of Awokpa, this means "organise meetings to explain how the management is done". He specified that it was necessary to "make the accounts public".

Extension of the network:

For a respondent from the village of Awokpa, it is necessary to "manage the infrastructure well and build others with the income from sales". And according to this respondent in the village of Djoko, "to ensure the sustainability of the structures, it should be possible to multiply them in order to slow down the wear and tear of the structures". In reality, it is a right for the population that the network extends into their village. In this sense, a respondent from the village of Awokpa argues that it is important to "build other castles" and that it is necessary to: "demand the extension of the works".

\section{Discussion}

\subsection{Private Sector Responsibilities}

The Dublin Conference in 1992 promoted the involvement of the private sector in the management of waterworks. As Botton (2017) points out, "following the Dublin Conference, which gave water the status of a 'social and economic good', the management of water services has gradually opened up to private sector participation (Botton, 2017).” At the local level, according to Bonnassieux \& Gangneron (2011), "private operators are responsible for the management of AEV and $\mathrm{FPM}^{3}$ in front of the municipalities, which are considered to be the owners of the infrastructures and the project owners (Bonnassieux \& Gangneron, 2011)." The private operator, through its financing, ensures the feasibility of projects. For Botton (2017), "The company undertook to provide the necessary equipment (pipes, spanner) and to ensure the technical training of the workforce (training workshops on work techniques and work safety aspects) and communication with the whole community (Botton, 2017)." In this sense, for Richter ${ }^{3}$ Borehole with human powered pump. 
(2017), "private companies can play a constructive role in providing resources or expertise in situations where governments are weak and unable to adequately fulfil their role in water supply (Richter, 2017).” The question arises as to whether the use of the private sector to professionalise the management of drinking water schemes is an ideological or pragmatic choice.

From the analysis of the literature, it appears that there is a kind of flight to the future, as if the problem is displaced without being addressed. In reality, as long as we do not go back to the basics, it will be difficult to solve the problem. One of the basics is to ask whether people, all the water users and managers, know where the water comes from. If they realise that in the mentality of the people of the area, according to one of the founding myths of the people of the area, "it was a woman who, in times of water shortage, sacrificed herself, turned herself into water so that others could have something to drink", then the data should be able to change. Knowing that the water I use or manage is the fruit of another person's sacrifice implies many things: that I sacrifice myself, that I take others into account, that I protect this water, that I make sure that no one runs out.

There is a need for continuity between community management and private operators. The sale of water is a new profession for most private operators, and the use of capacities forged in the framework of community management is useful to ensure the functioning of the VCAs. Bonnassieux and Gangneron give the example of good practice in the village of Kolokondé. The smooth functioning of the management of the AEVs in this village bears witness to these processes of hybridisation between old and new management modes, and the local arrangements are the manifestation of this (Bonnassieux \& Gangneron, 2011).

The fact that the operator comes from the community and is very involved in local development, and that he shows rigour, competence and availability, is one of the conditions for the sustainability of this type of technical system. Moreover, insofar as the operator and the fountain workers agree to carry out certain tasks with little or no remuneration to enable the community to have water, this contributes to the balance of the AEV in a context of relatively narrow local markets.

The private operator must be able to espouse the culture and ethics of water present in the area. It should be noted that the private operator has an ethic towards the user of the water point. As Zérah (2017) explains, "a company to which the management of the service is delegated is in direct contact with the user and it must act responsibly and sensitively with regard to the diversity of the public it serves (Zérah, 2017).” Thus the private operator must strive to understand the logic of the local population. For Zérah (2017), "the multinational must constantly deal with professional cultures that it discovers, that it perceives as inefficient and deviant and whose criteria of rationality must be understood" (Zérah, 2017).

The ethics of economic operators, which aim for economic profitability and 
the sustainability of the system, are based on the user-pays principle. This principle, as Botton (2017) writes, is "dear to the hearts of international financial institutions (Botton, 2017)." One of the positive aspects of the ethics of economic operators is the extension of the network, they invest and expect the return on investment. They are concerned about the security of their investment. Thus, as Botton (2017) shows, "although the transition from public to private management has been widely denounced by many social actors, it has nevertheless enabled a whole fringe of the urban population to have sustainable access-de jure and de facto-against payment—-to water services (Botton, 2017).”

\subsection{Social Dimension of Pricing}

The vast majority of the populations interviewed in the study area are of the opinion that users pay for drinking water. They are aware that there is a social dimension in the pricing of water in relation to its real cost. For Payen (2013), "The price and cost of drinking water are usually confused. Contrary to public opinion, on average around the world, the price of water is much lower than its cost!" (Payen, 2013). According to Payen's (2013) explanation, “Two mechanisms ensure that the majority of users pay a price below the average cost of drinking water in their locality. Firstly, it is rare that the utility's turnover is able to compensate for the full cost. Even in developed countries, some of these costs are covered by subsidies from public budgets. In developing countries, the situation is much worse (Payen, 2013)." As Payen (2013) points out, "it is estimated that more than $40 \%$ of operators there have a turnover that does not even reach their operating costs! They can only subsist with balancing subsidies voted a posteriori (Payen, 2013)." Thus, in general, as Payen (2013) shows, "the price of water paid by the population is often lower than the real cost of the service (Payen, 2013)." This is normal, as access to drinking water is a social issue and vital.

Apart from the price of water, which is lower than its real cost, there is solidarity between large and small consumers. As Payen (2013) argues, "the policy of a single identical tariff for all users in the same locality is a minority in the world, rather reserved for rich countries (Payen, 2013)." According to Payen's explanation, "In the majority of developing countries, tariff schedules include several differentiated prices according to the types of users or their consumption. This leads some users such as businesses (Colombia) or large consumers to subsidise other numerically more numerous users (Payen, 2013).” Payen (2013) gives the example of Morocco, "In Tangier, Morocco, a third of the inhabitants pay less per cubic metre of water than the operator pays to buy it from the company that purifies the water. Clearly, they are not contributing to the cost of building and running the network. It is the other consumers who pay all of these costs (Payen, 2013)." And the question arises according to Payen (2013), "Who pays the difference?" The answer is that, "It is still the population; through a different channel: taxes. The cost of drinking water is therefore essentially borne by the users and by the taxpayers (Payen, 2013)." 
It is true that water has a cost and a price. According to Richter (2017), "Many people believe that, in line with the philosophy that access to water is a basic human right, water should be distributed free of charge" (Richter, 2017). And as Richter (2017) explains, "For water managers this sentiment makes it politically difficult to generate sufficient revenue while adopting a water pricing policy that keeps water systems functioning (Richter, 2017).” Furthermore, for Richter (2017), "While the price of water should be subsidised or kept as low as possible for the poorest people in our society, everyone should understand that we also have to pay to fund the services needed to manage our water supply (Richter, 2017)." But given the cultural significance of water, the social dimension of pricing must be emphasised. In this sense, Bujo (1992) argues that "Profitability should not be the first criterion, but the humanisation of man in his cosmic dimension (Bujo, 1992)."

Water, in local symbolism, is the fruit of sacrifice, the gift that people have made of themselves. And in the dynamics of the gift, one cannot opt to sell water and even increase the price of water on the pretext that the profits will feed the communal budget. One cannot rely on social welfare to finance the functioning of an institution. Thus the municipality must be able to find other sources of funding and not expect to make a profit on water, which is life and should be free. As Singleton (2010) shows, "A well whereas many people as possible can come and draw for nothing the gift of water that God and/or Fate has given to humanity, that is the ideal" (Singleton, 2010). According to Singleton (2010) "privatizations, no matter on what scale, that benefit some, however small, would be far more equivocal (Singleton, 2010)." For Singleton (2010) "that a non-profit cooperative might take over the distribution of water is understandable; that a company should do so, not to provide a service but to make a profit, would be ultimately reprehensible (Singleton, 2010).” Thus it emerges, as Côté (2006) shows, that "beyond the economic discourse, there are ethical arguments in favour of water accessibility: equity, intergenerational solidarity and social justice (Côté, 2006).”

Richter (2017) notes that "Water policy experts around the world are now emphasising the need to move away from reliance on the centralised and hierarchical management of governmental water management technocracies and the need to move towards integrated and sustainable water governance systems (Richter, 2017)." In a similar vein, Botton (2017) refers to a "participatory management model” (PMM) for concessional slums. For Botton (2017) "All intervention modalities (decision-making process, operational phase of the works and commercial management) were adapted to the specificities of the poor neighbourhoods and were subject to a tripartite contract (between the inhabitants, the company and the municipality) supervised by the regulator (Botton, 2017)." Three main actors have been identified at the local level for the sustainable management of waterworks for access to drinking water. These are the local authorities representing the state, the consumers representing the populations and the companies representing the private sector. As Richter (2017) notes, 
"History has clearly shown that when local citizens, communities and businesses are more actively involved in designing how they manage water and work together to solve problems, the prospects for success greatly increase (Richter, 2017)."

\section{Conclusion}

The reflection on the philosophical foundations of corporate social responsibility in the water sector leads to a paradigm shift in water management. It leads to the need for an integrated, tripartite management system of waterworks for access to drinking water. Access to drinking water is a vital issue. And when life is at stake, all stakeholders must do their best to ensure that life is safeguarded. The sustainability of life on earth is at stake. And in this, the responsibility of all is engaged. The commitment of all stakeholders is required. Thus, the State through the communal services to guarantees the fundamental human right of access to drinking water, the populations to show that water is a common good, and the private operator to provide rigorous economic management, extension and sustainability of the drinking water supply network. African cultures in general and the Ayizo culture in the context of this study are full of images to symbolise the vital nature of water. Many values surround water in this culture. It is important to make a plea to remove water from the register of capitalism because water by its vital character is essentially social.

\section{Conflicts of Interest}

The authors declare no conflicts of interest regarding the publication of this paper.

\section{References}

Bonnassieux, A., \& Gangneron, F. (2011). Des mini-réseaux d'eau potable: entre enjeux politiques et arrangements locaux. Le cas de la commune de Djougou au Bénin. Mondes en développement, 155, 77-92. https://doi.org/10.3917/med.155.0077

Botton, S. (2017). Multinationales et services publics marchands de l'eau: éthique, drabilité, équité. Le cas de la concession Aguas Argentinas à Buenos Aires 1993-2006. In J.-P. Pierron (ed.), Ecologie politique de l'eau. Rationalités, usages et imaginaires (pp. 431-453). Hermann Editeurs. https://doi.org/10.3917/herm.pierr.2017.01.0431

Bujo, B. (1992). La conception négro-africaine de la nature et le problème de l'écologie. Ethique et natures (pp. 149-159). Labor et Fides.

Côté, M.-C. (2006). La gestion de l'eau au Québec: notre responsabilité vis-à-vis des générations futures. Mémoire de Maîtrise, Université du Québec.

Diop, C. M., \& Bah, A. N. (2018). Peut-on parler de l'émergence d'un modèle RSE africain: la situation du Sénégal? Revue congolaise de gestion, 25, 67-96. https://doi.org/10.3917/rcg.025.0067 https://www.cairn.info/revue-congolaise-de-gestion-2018-1-page-67.htm

Fahala, A. A. (2016). Monographie de la commune de Zè. Afrique Conseil, Cotonou, 27 p.

INSAE (2016). Effectifs de la population des villages et quartiers de ville du Bénin. INSAE, Cotonou, $83 \mathrm{p}$. 
Jonas, H. (1995). Le principe responsabilité. Flammarion.

Jonas, H. (1998). Pour une éthique du futur. Payot et Rivages.

Larrère, C., \& Larrère, R. (2009). Du bon usage de la nature. Pour une philosophie de l'environnement, Paris, Flammarion, 356 p.

Maillard, N. (2011). La vulnérabilité, une nouvelle catégorie morale? Labor et Fides.

Maneglier, H., \& Schleiss, M. (2000). L'ABCdaire de l'Eau. Flammarion.

Mêliho, C. P. (2014). Constructions sociales des risques de maladies autour de l'eau en milieu milieu Ayizo de Sèdjè-Hwégoudo à Zè(Sud-Bénin). Thèse de Doctorat unique, Université d'Abomey-Calavi.

Moreau, N. (2013). Professionnaliser les acteurs pour une gestion durable du service public de l'eau des communes de Kpomassè, Toffo et Zè. Cotonou.

Noutaï, G. (2017). Instituteur à Houéhounta. (C. Ahouandjinou, Intervieweur).

Payen, G. (2013). De l'eau pour tous! Abandonner les idées reçues, affronter les réalités. Armand Colin.

Rameix, S. (1996). Fondements philosophiques de l'éthique médicale. Ellipses.

Richter, B. (2017). La crise de l'eau, guide pratique pour une gestion durable. De Boeck Supérieur.

Semde, C. (2015). Ethique et politique chez Hans Jonas. Pour une philosophie politique de l'environnement. L'Harmattan.

Singleton, M. (2010). Histoires d'eaux africaines. Essais d'anthropologie impliquée. BruylantAcademia s.a.

Zérah, M.-H. (2017). La multinationale à l'épreuve des cultures de l'eau. Réflexions à partir du cas de Nagpur (Inde). In J.-P. Pierron (ed.), Ecologie politique de l'eau. Rationalités, usages et imaginaires (pp. 455-463). Hermann Editeurs.

https://doi.org/10.3917/herm.pierr.2017.01.0455 